Volume 5 Mei, 2020 (81-93)

JTIKOR (Jurnal Terapan Ilmu Keolahragaan)

http://eiournal.upi.edu/index.php/JTIKOR

doi: $\underline{10.17509 / \text { itikor.v5i1.25097 }}$

\title{
NUTRISI BAGI ATLET REMAJA
}

\section{Syarifah Zahra ${ }^{\bowtie u h l i s i n ~}$}

Pendidikan Jasmani kesehatan \& Rekreasi, FKIP, Universitas Wahid Hasyim

\section{Info Artikel}

\section{Kata Kunci:}

Atlet remaja, latihan, kalori, nutrisi.

Keywords:

Young athlete, training, calories nutrition.

\footnotetext{
Alamat korespondensi: Kampus Universitas Wahid Hasyim Semarang, J1 Menoreh $\mathrm{X} / 22$ Sampangan

E-mail: szahrapikr@gmail.com muchlisin@unwahas.ac.id
}

\begin{abstract}
Abstrak
Atlet membutuhkan nutrisi yang lebih dibandingkan orang biasa. Kebutuhan Nutrisi bagi atlet remaja penting sebagai suplemen untuk menghasilkan energi, pertumbuhan, performa maupun proses dalam pemulihan (recovery). Artikel ini bertujuan menjelaskan aspek apa saja yang harus diperhatikan dalam memenuhi nutrisi bagi atlet remaja. Jenis penelitian ini adalah penelitan kepustakaan (library research). Metode pengumpulan data menggunakan metode dokumentasi (literasi). Analisis data yang digunakan dalam penelitian ini adalah analisis anotasi bibliografi (annotated bibliography). Beberapa aspek penting dalam pemenuhan nutrisi atlet remaja antara lain: Aspek kebutuhan kalori (calorie needs), makro nutrient (macro nutrient), hidrasi (hydration), waktu (timing), dan suplemen (supplementation). Semua aspek pemenuhan nutrisi bagi atlet remaja adalah sama pentingnya untuk menunjang performa khususnya pada atlet remaja.
\end{abstract}

\section{Abstract}

Athletes need more nutrition than ordinary people. Nutrition needs for adolescent athletes are important as a supplement to produce energy, growth, performance and recovery processes. This article aims to explain what aspects must be considered in meeting nutrition for adolescent athletes. This type of research is library research. The data collection method uses the documentation (literacy) method. Analysis of the data used in this study is the analysis of bibliographic annotations (annotated bibliography). Some important aspects in fulfilling the nutrition of adolescent athletes include: Calorie needs, macro nutrients, hydration, timing, and supplementation. All aspects of fulfilling nutrition for adolescent athletes are equally important to support performance, especially in adolescent athletes. 


\section{PENDAHULUAN}

Atlet merupakan seseorang yang memiliki tingkat kebutuhan energi yang lebih dibandingkan orang biasa. atlet sangat membutuhkan asupan Nutrisi yang lebih dibandingkan orang biasa. Kebutuhan Nutrisi bagi atlet penting sebagai suplemen untuk menghasilkan energi, pertumbuhan, performa maupun proses dalam pemulihan (recovery). Pemberian Nutrisi yang tepat untuk atlet berusia remaja tidak hanya penting untuk menjaga kesehatan dan mengoptimalkan kinerja selama latihan, tetapi juga sangat penting untuk memenuhi persyaratan pertumbuhan dan pembangunan (Sacheck, Ph, \& Schultz, 2016).

Atlet dengan kategori usia remaja, merupakan masa usia yang efektif dan penting dalam jenjang pembinaan olahraga. Sehingga penting untuk dapat memperhatikan setiap kebutuhan guna menunjang performa dan kinerja mereka selama latihan.

Pada masa pembinaan atlet remaja, penting bagi setiap atlet untuk mendapatkan manfaat sebanyak-banyaknya dari latihan, apakah latihan itu terkait dengan kekuatan, kekuatan, kecepatan, kelincahan, atau daya tahan. Tujuan dari setiap latihan yang dilakukan untuk mempersiapkan setiap atlet untuk berkompetisi dan meraih prestasi yang terbaik. Agar atlet dapat memperoleh manfaat dari setiap latihan, sangat penting bahwa pelatih maupun atlet memahami kebutuhan nutrisi yang tepat dan kebiasaan hidrasi sebelum dan sesudah sesi latihan. Selain itu, sangat penting bahwa pelatih juga menghindarkan kekurangan nutrisi dan hidrasi dalam hal kebiasaan sebelum dan sesudah pertandingan maupun untuk berkontribusi pada kinerja serta proses pemulihan setelah kompetisi.

Nutrisi dasar penting untuk pertumbuhan bagi atlet remaja untuk mencapai kesehatan yang baik, pencapaian skolastik, dan menyediakan energi. Nutrisi olahraga meningkatkan kinerja saat latihan maupun bertanding dengan mengurangi kelelahan dan risiko penyakit dan cedera; itu juga memungkinkan atlet untuk mengoptimalkan latihan dan pulih lebih cepat Nutrisi yang tepat akan menyeimbangkan asupan energi dengan pengeluaran energi. Hal ini sangat penting untuk mencegah defisit atau kelebihan energi. Defisit energi dapat menyebabkan perawakan pendek, pubertas tertunda, disfungsi menstruasi, kehilangan massa otot dan meningkatnya kerentanan terhadap kelelahan, cedera atau penyakit Sedangkan kelebihan energi menyebabkan kelebihan berat badan dan obesitas.

Dalam beberapa artikel penelitian sebelumnya penulis belum menemukan artikel yang menjelaskan aspek yang perlu diperhatikan dalam pemenuhan nutrisi bagi atlet khususnya atlet remaja.

Beberapa artikel penelitian/jurnal yang ditemukan secara terpisah membahas kebutuhan nutrisi bagi atlet remaja dan belum menyinggung tentang aspek -aspek yang perlu diperhatikan secara khusus.

Artikel ini menjawab pertanyaan tentang aspek yang harus diperhatikan dalam pemenuhan kebutuhan atlet dengan kategori atlet remaja.

\section{METODE}

Penelitian kepustakaan atau kajian literatur (literature review, literature research) merupakan penelitian yang mengkaji atau meninjau secara kritis pengetahuan, gagasan, atau temuan yang terdapat di dalam tubuh literatur berorientasi akademik (academicoriented literature), serta merumuskan kontribusi teoritis dan metodologisnya untuk topik tertentu

Jenis penelitian ini adalah penelitan kepustakaan (library research), yaitu penelitian yang berkenaan dengan metode pengumpulan data pustaka, atau penelitian yang obyek penelitiannya digali melalui beragam informasi kepustakaan (buku, ensiklopedi, jurnal ilmiah, koran, majalah, dan dokumen).

\section{Sumber Data}

Data yang digunakan dalam penelitian ini adalah data sekunder. Data sekunder merupakan data yang diperoleh bukan dari pengamatan langsung. Akan tetapi data tersebut 
diperoleh dari hasil penelitian yang telah dilakukan oleh peneliti-peneliti terdahulu. Sumber data sekunder yang dimaksud berupa buku danlaporan ilmiah primer atau asli yang terdapat di dalam artikel, sumber internet, buku atau jurnal (tercetak dan/atau non-cetak).

Pemilihan sumber didasarkan pada empat aspek yakni 1) Provenance (bukti), 2) Objectivity (Objektifitas) ,3) Persuasiveness (keyakinan), dan 4) Value (nilai kontributif),

\section{Metode Pengumpulan Data}

Metode pengumpulan data menggunakan metode dokumentasi. Metode dokumentasi yaitu metode pengumpulan data dengan menggali data dari literatur yang terkait dengan apa yang dimaksudkan dalam rumusan masalah. Data-data yang telah didapatkan dari berbagai literatur dikumpulkan sebagai suatu kesatuan dokumen yang digunakan untuk menjawab rumusan masalah.

\section{Prosedur}

Terdapat empat prosedur yang digunakan dalam peneltian ini yakni: 1) Organize, yakni mengorganisasi literatur yang relevan/sesuai dengan permasalahan yang ditinjau/di-review. 2) Synthesize, yakni menyatukan hasil literatur menjadi suatu ringkasan agar menjadi satu, dengan mencari keterkaitan antar literatur; 3) Identify, yakni mengidentifikasi hal-hal yang dianggap sangat penting untuk dikupas atau dianalisis, guna mendapatkan suatu tulisan yang menarik untuk dibaca;dan (4) Formulate, yakni merumuskan jawaban dari pertanyaan yang dibutuhkan dalam penelitian lebih lanjut.

\section{Analisis Data}

Analisis data yang digunakan dalam penelitian ini adalah analisis anotasi bibliografi (annotated bibliography). Anotasi berarti suatu kesimpulan sederhana dari suatu artikel, buku, jurnal, atau beberapa sumber tulisan yang lain, sedangkan bibliografi diartikan sebagai suatu daftar sumber dari suatu topik

\section{HASIL}

Penelitian dilakukan dengan melakukan review beberapa buku dan artikel dari beberapa sumber. Adapun sebagai bahan review utama buku antara lain:

1. Buku berjudul Nutrition for the young athlete. Meyer F, O'Connor H, Shirreffs SM. (2009).

2. Buku dari Ronald J. Maughan. (2000) yang berjudul Nutrition in Sport

3. Ilaria St. Florian, MS, RD. (2018). The 101 on Nutrition in Young Athletes.

Dan beberapa artikel, jurnal dan buku pendukung sebagai sumber pendukung sebagai berikut:

1. Smith JEW, Holmes ME, McAllister MJ melalui jurnal Nutritional Considerations for Performance in Young Athletes (2015) tentang kebutuhan nutrisi pada atlet remaja.

2. Jurnal pedriatic dengan judul Sports Drinks and Energy Drinks for Children and Adolescents: Are They Appropriate? 2011. Dipublikasi oleh Committee on Nutrition and the Council on Sports Medicine and Fitness

3. Ben Desbrow, Nicholas A Burd, etc. (2019). Nutrition for Special Populations: Young, Female, and Masters Athletes (Journal) International Journal of Sport Nutrition, Exercise and metabolism

4. Jovanov Pavle , Đorđić Višnja , etc (2019) Prevalence, Knowledge and Attitudes Towards Using Sports Supplements Among Young Athletes. Journal of International Society of Sport Nutrition

Secara umum atlet memiliki kebutuhan kalori 2.000/kkal perhari untuk memenuhi kebutuhan energinya. Sedangkan bagi atlet kebutuhan tersebut secara mendasar tidak cukup dengan level aktifitas yang relative tinggi. Kebutuhan kalori seseorang akan dipengaruhi oleh beberapa faktor antara lain usia, jenis kelamin, berat badan, olahraga, tingkat aktivitas, durasi aktifitas, dan kesehatan keseluruhan orang tersebut

Berdasarkan beberapa rujukan dalam penelitian ini dapat dirangkum beberapa hasil literasi mengenai aspak yang harus diperhatikan dalam pemenuhan kebutuhan nutrisi sebagai berikut:

\section{Kebutuhan kalori (Calorie Needs)}

Atlet harus mengkonsumsi energi yang cukup, atau kalori, setiap hari untuk memenuhi 
berat dan tujuan komposisi tubuh mereka, apakah itu untuk mempertahankan berat badan, menurunkan berat badan atau menambah berat badan. Untuk menjaga keseimbangan energi, asupan makanan, cairan, dan suplemen untuk pengeluaran energi.

Agar atlet memenuhi kebutuhan energinya, mereka harus mengonsumsi kalori yang cukup. Jika kebutuhan energi tidak terpenuhi, lemak dan jaringan tubuh tanpa lemak akan digunakan sebagai bahan bakar oleh tubuh. Ini akan menyebabkan hilangnya kekuatan dan daya tahan. Fungsi imun, endokrin, dan muskuloskeletal akan terganggu. Seiring waktu, asupan rendah kalori dapat menyebabkan laju metabolisme istirahat yang lebih lambat, dan konsumsi vitamin dan mineral esensial yang tidak mencukupi.

Ada beberapa metode untuk menghitung kebutuhan energi untuk atlet. Metode sederhana untuk menghitung kebutuhan energi adalah dengan menghitung berat atlet (dalam pound) dikalikan dengan 10 untuk rata-rata kasar dari kebutuhan basal, atau kebutuhan dasar tanpa latihan apa pun. Kemudian, tambahkan faktor aktivitas dan rata-rata kalori yang terbakar untuk setiap menit olahraga

Sebagai contoh:

Atlet dengan berat badan 220 Pon dapat diitung dengan berat badan $\times 10$

Jadi $220 \times 10=2,200$ Kalori (artinya kebutuhan dasar seseorang adalah 2200 kalori/hari)

Untuk aktifitas fisik tambahkan 20\%-30\% dari kebutuhan dasar kalori.

Jadi 2,200 x 1.2 - 1.3 = 2,640 - 2,860 Kalori

Terakhir, tambahkan kalori olahraga dengan menambahkan 100 kalori untuk setiap 10 menit latihan berat. Dalam contoh ini, jika atlet berlatih keras selama rata-rata /hari maka bisa ditambahkan kalori sebanyak tambahan 1.800 kalori.

Total kebutuhan kalori $=2,640-2,860$ kalori + 1,800 calories $=$ an average of $4,400-4,660$ calories per day
Tabel 1. Kebutuhan kalori berdasarkan usia dan level aktifitas pada Laki-laki

\begin{tabular}{|c|c|c|c|}
\hline USIA & NORMAL & AKTIF & SANGAT AKTIF \\
\hline 12 & 1,800 & 2,200 & 2,400 \\
\hline 13 & 2,000 & 2,200 & 2600 \\
\hline 14 & 2,000 & 2,400 & 2800 \\
\hline 15 & 2,200 & 2,600 & 3000 \\
\hline 16 & 2,400 & 2,800 & 3200 \\
\hline 17 & 2,400 & 2,800 & 3200 \\
\hline 18 & 2,400 & 2,800 & 3200 \\
\hline $19-20$ & 2,600 & 2,800 & 3000 \\
\hline
\end{tabular}

Asupan energi yang direkomendasikan berdasarkan Estimated Energi Requirements (EER) dari Institute of Medicine Dietary Reference Intakes makronutrien, 2002

Kebutuhan kalori untuk atlet remaja bergantung pada usia, jenis kelamin, dan tingkat aktivitas fisik. Dalam beberapa jenis olahraga tertentu, remaja rata-rata menghabiskan sekitar 10-25 \% Energi lebih banyak dibandingkan orang dewasa. Berikut kebutuhan kalori pada atlet berdasarkan kategori usia.

Tabel 2. Kebutuhan kalori berdasarkan usia dan level aktifitas pada Perempuan

\begin{tabular}{|c|c|c|c|}
\hline USIA & NORMAL & AKTIF & SANGAT AKTIF \\
\hline 12 & 1,600 & 2,000 & 2,200 \\
\hline 13 & 1,600 & 2,000 & 2,200 \\
\hline 14 & 1,800 & 2,000 & 2,400 \\
\hline 15 & 1,800 & 2,000 & 2,400 \\
\hline 16 & 1,800 & 2,000 & 2,400 \\
\hline 17 & 1,800 & 2,000 & 2,400 \\
\hline 18 & 1,800 & 2,000 & 2,400 \\
\hline $19-20$ & 2,000 & 2,200 & 2,400 \\
\hline
\end{tabular}

Asupan energi yang direkomendasikan berdasarkan Estimated Energi Requirements (EER) dari Institute of Medicine Dietary Reference Intakes makronutrien, 2002

Nutrisi yang tepat sangat penting bagi atlet remaja untuk mencapai pertumbuhan yang dan penampilan optimal dalam olahraga. Atlet remaja perlu belajar makanan apa yang baik untuk energi, kapan harus makan makanan tertentu, bagaimana makan selama acara, dan kapan dan apa yang harus dimakan untuk diisi kembali setelah aktivitas. Diet seimbang yang mengandung jumlah makronutrien (protein, karbohidrat dan lemak) dan mikronutrien (vitamin dan mineral) yang tepat sangat penting untuk menyediakan energi yang cukup untuk 
pertumbuhan dan aktivitas. Cairan juga penting untuk hidrasi untuk mendukung pertumbuhan dan perkembangan. Jumlah energi yang ditemukan dalam makanan yang diberikan tergantung pada kandungan makronutrien (karbohidrat, protein dan lemak) dari item tersebut.

Tabel 3. Kandungan Energi dalam makronutrien (dalam gram)

\begin{tabular}{|l|l|}
\hline Makronutrien & Energi \\
\hline Karbohidrat & $4 \mathrm{kkal} /$ gram \\
\hline Protein & $4 \mathrm{kkal} /$ gram \\
\hline Lemak & $9 \mathrm{kkal} /$ gram \\
\hline
\end{tabular}

Karbohidrat berfungsi sebagai sumber energi utama selama aktivitas dengan intensitas lebih tinggi. Sumber makanan karbohidrat sehat termasuk buah-buahan, sayuran, sereal gandum, roti dan pasta. Lemak berperan penting dalam membantu individu memenuhi kebutuhan energi mereka serta mendukung kadar hormon yang sehat. Sumber lemak sehat termasuk kacang-kacangan, mentega kacang, alpukat, minyak zaitun dan kelapa. Batasi penggunaan minyak nabati seperti jagung, biji kapas atau minyak kedelai. Protein berperan penting dalam perbaikan dan pertumbuhan otot. Sumber protein yang disukai termasuk daging tanpa lemak, telur, susu (yogurt, susu, keju cottage) dan kacang-kacangan.

\section{Makronutrient (Macronutrient)}

Makronutrien adalah makanan utama yang membantu tubuh dan membentuk energi. Makronutrien terdiri dari 3 bagian utama yaitu lemak, protein dan karbohidrat. Makronutrien yaitu zat gizi yang banyak menyumbang energi bagi tubuh. Dala istilah makronutrien menggambarkan zat kimia yang memberikan kalori untuk energi termasuk karbohidrat, protein dan lemak. Tubuh memerlukan nutrisinutrisi tersebut dalam jumlah banyak.

Didalam ilmu gizi, yang dinamakan makronutrien adalah zat gizi yaitu karbohidrat, proteindan lemak. Sedangkan mikronutrien adalah vitamin dan mineral. Kedua zat ini adalah merupakan unsur penting dalam makanan sehari-hari dan kecukupan kedua unsur tersebut merupakan kunci akan tercapainya prestasi atlet.

Pada umumnya kebutuhannya makronutrien tetap sesuai pekerjaan, sedang pada atlet, kebutuhannya harus sesuai dengan macam olahraga, lama olahraga dan berat badan. Makin berat intensitas olahraga tersebut, maka makin banyak dibutuhkan kedua zat tersebut. Kebutuhan KH (Karbohidrat) biasanya $55-70 \%$ dari jumlah kalori, lalu protein $20 \%$ dan sisanya lemak $10-20 \%$.

Menyeimbangkan asupan energi dengan pengeluaran energi sangat penting untuk mencegah defisit atau kelebihan energi. Defisit energi dapat menyebabkan perawakan pendek, pubertas tertunda, disfungsi menstruasi, kehilangan massa otot dan meningkatnya kerentanan terhadap kelelahan, cedera atau penyakit. Kelebihan energi dapat menyebabkan kelebihan berat badan dan obesitas. Sehingga perlu untuk mengetahui jenis makronutrien yang tepat sebagai penunjang Energi bagi atlet sehingga tidak mengalami kekurangan ataupun kelebihan energi dari makanan yang dikonsumsi.

Smith JEW, Holmes ME, McAllister MJ melalui jurnal Nutritional Considerations for Performance in Young Athletes (2015) memberi rekomendasi kebutuhan makronutrien untuk atlet usia remaja sebagai berikut.

Tabel 5. Kebutuhan dasar Makronutrien Untuk Atlet Remaja

\begin{tabular}{|c|c|}
\hline Makronutrien & Kebutuhan \\
\hline Karbohidrat & $\begin{array}{c}50 \% \text { dari asupan kalori, dengan } \\
\text { total 3-8g / kg berat badan. 1-1,5 } \\
\text { g / kg berat badan pasca latihan / } \\
\text { latihan.7 }\end{array}$ \\
\hline Protein & $\begin{array}{l}\text { 0,8-1,2 g / s.d 1.2-1.8 g / kg berat } \\
\text { atau sekitar 10\% hingga 30\% } \\
\text { dari total asupan energi. }\end{array}$ \\
\hline Lemak & $\begin{array}{c}20-25 \% \text { dari asupan kalori, tidak } \\
\text { kurang dari 15\%. }\end{array}$ \\
\hline
\end{tabular}


Berikut detail kebutuhan makronutrien untuk atlet usia remaja sebagai penunjang kebutuhan energi dalam berolahraga.

Kebutuhan nutrisi pada masa remaja lebih tinggi dibandingkan orang dewasa dalam siklus hidup (Croll et al. 2006). Bahkan untuk remaja yang tidak melakukan aktifitas olahraga, remaja membutuhkan campuran kalori, karbohidrat, lemak, dan protein yang sehat. Antara untuk dapat memicu aktifitas dan menyeimbangkan dengan pertumbuhan tubuh mereka.

\section{$\underline{\text { Karbohidrat }}$}

Karbohidrat adalah sumber bahan bakar paling penting bagi para atlet karena mereka menyediakan glukosa yang digunakan untuk energi. Satu gram karbohidrat mengandung sekitar empat kilokalori energi.

Glukosa disimpan sebagai glikogen di otot dan hati. Glikogen otot adalah sumber energi yang paling remajah tersedia untuk otot yang bekerja dan dapat dilepaskan lebih cepat daripada sumber energi lainnya (1). Karbohidrat harus terdiri dari $45 \%$ hingga $65 \%$ dari total asupan kalori untuk anak berusia empat hingga 18 tahun $(1,7)$. Sumber karbohidrat yang baik termasuk serealia utuh, sayuran, buah-buahan, susu dan yogurt.

Studi menunjukkan bahwa karbohidrat harus dikonsumsi setiap hari, terutama setelah berolahraga. Hal ini untuk mengembalikan kadar karbohidrat (glikogen) yang akan disimpan dalam otot dan hati. Pada atlet remaja paling tidak harus mendapatkan 50 hingga 55\% dari total kalori mereka dalam bentuk karbohidrat, atau sekitar 2,7 gram per pon berat badan. Seorang atlet remaja yang membutuhkan 2.500 kalori per hari perlu makan setidaknya 313 hingga 343 gram karbohidrat per hari (ada 4 kalori dalam 1 gram karbohidrat).

Karbohidrat, seperti halnya dengan kalori, harus diberikan secara imbang atau proporsional terutama pada atlet remaja. Hal ini karena terlalu banyak Karbohidrat dari sumber yang salah dapat menyebabkan penambahan berat badan dan resistensi insulin (Kocsis, 2006). Sedangkan karbohidrat yang tidak cukup akan meningkatkan peluang untuk kelelahan dan berdampak negatif pada performa (Saskatchewan, 2013). Sekali lagi, atlet dan orang tua yang penting memahami cara untuk mencapai keseimbangan.

Tabel 6. Kebutuhan karbohidrat (g) per kg dari berat badan

\begin{tabular}{|c|c|}
\hline $\begin{array}{c}\text { Durasi Latihan } \\
\text { (jam) }\end{array}$ & $\begin{array}{c}\text { Karbohidrat (g) per Kg } \\
\text { dari berat badan. }\end{array}$ \\
\hline 0 s.d 1 & 5 s.d 6 \\
\hline 1 s.d 2 & 6 s.d 7 \\
\hline 2 s.d 3 & 7 s.d 8 \\
\hline lebih dari 4 & 8 s.d 10 \\
\hline
\end{tabular}

Bean, A. (2013) Sports nutrition for young athletes. London: Bloomsbury Publishing.

Otot membakar Protein, Lemak dan Karbohidrat sebagai bahan bakar selama latihan, jumlah masing-masing tergantung pada panjang dan intensitas latihan. Sudah diterima secara luas bahwa semakin besar intensitas olahraga semakin banyak otot Anda akan menggunakan simpanan karbohidrat untuk bahan bakar (Bean, 2013).

Sumber karbohidrat yang kaya nutrisi berasal dari buah, sayuran, kacang-kacangan dan sereal. Kacang-kacangan dan gandum memiliki banyak nutrisi dan serat, sedangkan buah dan sayuran memberikan vitamin dan mineral penting, A dan C, phytochemical dan serat.

Selain kepadatan nutrisi, indeks glikemik atau beban harus dipertimbangkan. Indeks glikemik atau beban makanan adalah ukuran seberapa cepat itu menyebabkan kadar gula darah untuk naik atau turun. Makanan dengan kandungan glisemik tinggi, diperoleh dari gula sederhana dan halus (mis. permen, roti putih, putih beras), tidak akan menyediakan energi berkelanjutan dan perlu dihindari, terutama sebelum latihan. Makanan dengan kandungan glisemik rendah membantu mempertahankan kadar gula darah stabil sepanjang hari dan selama berolahraga. 


\section{Protein}

Protein berfungsi membangun dan memperbaiki otot, rambut, kuku, kulit dan jaringan lainnya. Untuk olahraga ringan dan olahraga berdurasi pendek, protein tidak bertindak sebagai sumber energi utama. Namun, dengan meningkatnya durasi olahraga, protein membantu menjaga glukosa darah melalui glukoneogenesis hati.

Kebutuhan protein harian masing-masing individu sangat bervariasi. Rekomendasi standar untuk atlet remaja yang sedang tumbuh adalah untuk mengonsumsi 0,6 hingga 0,9 Gram protein per pon berat badan setiap harinya. Sebagai contoh, seorang atlet dengan berat 150 pound harus mengkonsumsi antara 105 dan 135 Gram protein per hari. Asupan protein tidak hanya tergantung pada tingkat aktivitas fisik tetapi juga pada tingkat pertumbuhan atau penyembuhan setiap atlet. Atlet yang sedang dalam masa pertumbuhan kritis, atau pubertas mungkin membutuhkan lebih banyak protein dalam diet mereka.

Dalam mengkonsumsi protein pada atlet remaja perlu untuk menentukan berapa banyak protein dibutuhkan. Seorang atlet remaja yang memiliki frekuensi latihan 3-4 hari perminggu memerlukan paling tidak 1,0 gram / $\mathrm{kg} /$ hari. Untuk atlet yang memiliki intensitas tinggi dan untuk meningkatkan volume otot paling tidak memerlukan protein yang lebih tinggi yaitu 1,7 gram / kg / hari.

Satu gram protein menyediakan empat kilokalori energi. Protein harus terdiri dari sekitar 10\% hingga 30\% dari total asupan energi untuk anak berusia empat hingga 18 tahun (7). Sumber protein yang baik termasuk daging tanpa lemak dan unggas, ikan, telur, produk susu, kacang-kacangan dan kacang-kacangan, termasuk kacang tanah.

\section{Lemak}

Lemak diperlukan untuk menyerap vitamin yang larut dalam lemak (A, D, E, K), untuk menyediakan asam lemak esensial, melindungi organ vital dan menyediakan isolasi. Lemak juga memberikan perasaan kenyang. Ini adalah sumber energi yang padat kalori (satu gram menyediakan sembilan kilokalori) tetapi lebih sulit untuk digunakan.

Lemak harus terdiri dari 20\% hingga 25\% dari total asupan energi untuk anak berusia empat hingga 18 tahun (7). Lemak jenuh harus terdiri tidak lebih dari $10 \%$ dari total asupan energi $(1,3)$. Sumber lemak yang baik termasuk daging tanpa lemak dan unggas, ikan, kacangkacangan, biji-bijian, produk susu, dan minyak zaitun dan minyak kanola. Lemak dari keripik, permen, makanan yang digoreng, dan makanan yang dipanggang harus diminimalkan.

Terkadang asumsi atlet terhadap lemak cenderung negatif. Lemak merupakan makronutrien yang memiliki waktu pencernaan lama dan cenderung disimpan apabila tidak digunakan. Sehingga lemak dainggap sebagai penyebab utama pada kelebihan berat badan dan efek kesehatan lainnya. Untuk itu perlu memberikan pemahaman mengenai lemah sehat yang perlu dan dibutuhkan oleh atlet terutama atlet remaja.

Remaja membutuhkan energi tidak hanya digunakan sebagai bahan energi saja, melainkan untuk kebutuhan pertumbuhan. Artinya membatasi lemak juga memiliki resiko pada pemenuhan kebutuhan energi.

\section{Mikronutrient (Micronutrient)}

Mikronutrien (zat gizi mikro) merupakan zat gizi yang dibutuhkan oleh tubuh dalam jumlah sedikit, namun mempunyai peran penting membentuk hormon, aktivitas enzim serta mengatur fungsi sistem imun dan sistem reproduksi.

Yang termasuk mikronutrien yaitu vitamin dan mineral. Mineral dibagi menjadi dua kelompok yaitu makromineral dan mikromineral. Makromineral adalah mineral yang dibutuhkan tubuh sebanyak minimal 100 mg per hari (contoh: kalsium, fosfor), sedangkan mikromineral (trace elements) adalah mineral yang dibutuhkan tubuh dalam jumlah kurang dari $100 \mathrm{mg}$ per hari (contoh: seng, besi). Mikromineral dibutuhkan dalam jumlah hanya beberapa mikrogram per hari, seperti cuprum dan molibdenum. Mikronutrien diperoleh dari luar tubuh seperti dari makanan 
atau suplemen, karena tubuh tidak mampu memproduksinya dalam jumlah yang cukup sesuai dengan kebutuhan tubuh.

Meskipun ada banyak vitamin dan mineral yang dibutuhkan untuk kesehatan, paling tidak perlu memastikan bahwa atlet mengonsumsi kalsium, vitamin $\mathrm{D}$, dan zat besi dalam jumlah yang tepat. Kalsium penting untuk kesehatan tulang, aktivitas enzim normal, dan kontraksi otot. Asupan kalsium yang direkomendasikan setiap hari adalah $1000 \mathrm{mg} /$ hari untuk anak usia empat hingga delapan tahun dan $1.300 \mathrm{mg} /$ hari untuk anak usia sembilan hingga 18 tahun $(7,8)$. Kalsium terkandung dalam berbagai makanan dan minuman, termasuk susu, yogurt, keju, brokoli, bayam dan produk biji-bijian.

Keterbatasan waktu pada atlet remaja dapat membuat diet seimbang menjadi sulit, sehingga dapat menimbulkan risiko defisiensi mikronutrien. Kekurangan ini paling sering diamati pada anak perempuan daripada anak laki-laki dan dalam asupan mineral daripada asupan vitamin. Atlet dengan kategori usia remaja sebenarnya lebih mungkin mencapai asupan vitamin daripada remaja non-atlet karena peningkatan asupan kalori total mereka.

Vitamin D diperlukan untuk kesehatan tulang dan terlibat dalam penyerapan dan pengaturan kalsium. Rekomendasi saat ini menyarankan $600 \mathrm{IU} /$ hari untuk anak berusia empat hingga 18 tahun (8). Nilai normal vitamin D juga bervariasi tergantung pada lokasi geografis dan ras. Atlet yang tinggal di garis lintang utara atau yang berlatih di dalam ruangan (misalnya, skater, pesenam, dancer) lebih cenderung kekurangan vitamin D. Sumber vitamin D termasuk makanan yang diperkaya, seperti susu, dan paparan sinar matahari. Produk susu selain susu, seperti yogurt, tidak mengandung vitamin $\mathrm{D}$.

Zat besi penting untuk sirkulasi oksigen ke jaringan tubuh. Selama masa remaja, dibutuhkan lebih banyak zat besi untuk mendukung pertumbuhan serta peningkatan volume darah dan massa otot tanpa lemak. Anak laki-laki dan perempuan berusia sembilan hingga 13 tahun harus mengonsumsi $8 \mathrm{mg} /$ hari untuk menghindari penipisan cadangan zat besi dan anemia defisiensi besi . Remaja 14 hingga 18 tahun membutuhkan lebih banyak zat besi, hingga $11 \mathrm{mg} /$ hari untuk pria dan $15 \mathrm{mg}$ / hari untuk wanita. Penipisan zat besi sering terjadi pada atlet karena diet yang buruk pada daging, ikan dan unggas, atau peningkatan kehilangan zat besi dalam urin, feses, keringat atau darah menstruasi. Oleh karena itu, atlet, terutama atlet wanita, vegetarian dan pelari jarak jauh harus secara berkala untuk mengetahui status zat besi.

Sementara itu mineral memainkan peran melalui pasokan natrium, kalium, zat besi, dan kalsium dalam tubuh. Sodium yang hilang saat latihan melalui melalui keringat, perlu diganti natrium selama latihan. Berkeringat saat berolahraga meningkatkan konsentrasi garam dalam tubuh, sehingga mengonsumsi garam setelah kompetisi dan latihan tidak disarankan. Ini akan menarik air keluar dari sel, menyebabkan otot lemah.

Berikut ini beberapa kebutuhan makronutrient pada atlet usia remaja dalam table-tabel berikut ini.

Tabel 7. Kebutuhan Mikronutrien berdasarkan jenis kelamin dan Usia

\begin{tabular}{|c|c|c|c|c|c|}
\hline \multirow{2}{*}{ USIA } & \multirow{2}{*}{ Kalsium } & \multirow{2}{*}{ Folat } & \multirow{2}{*}{$\begin{array}{c}\text { Vitamin } \\
\text { B6 }\end{array}$} & & \multicolumn{2}{|c|}{ Zat besi } \\
\cline { 5 - 6 } & & Min & Max \\
\hline $\begin{array}{c}\text { Semua Anak } \\
\text { 4 s.d } 8 \text { Tahun }\end{array}$ & $800 \mathrm{mg} / \mathrm{d}$ & $200 \mathrm{mcg} / \mathrm{d}$ & $0.6 \mathrm{mg} / \mathrm{d}$ & $10 \mathrm{mg} / \mathrm{d}$ & $40 \mathrm{mg} / \mathrm{d}$ \\
\hline $\begin{array}{c}\text { Laki -laki } \\
\text { 9s.d 13 Tahun }\end{array}$ & $1,300 \mathrm{mg} / \mathrm{d}$ & $300 \mathrm{mcg} / \mathrm{d}$ & $1 \mathrm{mg} / \mathrm{d}$ & $8 \mathrm{mg} / \mathrm{d}$ & $40 \mathrm{mg} / \mathrm{d}$ \\
\hline $\begin{array}{c}\text { Laki-Laki } \\
\text { 9s.d 13Tahun }\end{array}$ & $1,300 \mathrm{mg} / \mathrm{d}$ & $300 \mathrm{mcg} / \mathrm{d}$ & $1 \mathrm{mg} / \mathrm{d}$ & $8 \mathrm{mg} / \mathrm{d}$ & $40 \mathrm{mg} / \mathrm{d}$ \\
\hline $\begin{array}{c}\text { Perempuan } \\
\text { 14 s.d 18 Tahun }\end{array}$ & $1,300 \mathrm{mg} / \mathrm{d}$ & $400 \mathrm{mcg} / \mathrm{d}$ & $1.3 \mathrm{mg} / \mathrm{d}$ & $11 \mathrm{mg} / \mathrm{d}$ & $45 \mathrm{mg} / \mathrm{d}$ \\
\hline $\begin{array}{c}\text { Perempuan } \\
\text { 14 s.d 18Tahun }\end{array}$ & $1,300 \mathrm{mg} / \mathrm{d}$ & $400 \mathrm{mcg} / \mathrm{d}$ & $1.2 \mathrm{mg} / \mathrm{d}$ & $15 \mathrm{mg} / \mathrm{d}$ & $45 \mathrm{mg} / \mathrm{d}$ \\
\hline
\end{tabular}

Keterangan $: \mathrm{mg} / \mathrm{d}=$ milligram $/$ hari, $\mathrm{mcg} / \mathrm{d}=$ microgram $/$ hari

\section{Hidrasi (Hydration)}

Hidrasi diartikan sebagai keseimbangan cairan dalam tubuh. Hidrasi menjamin fungsi metabolisme sel tubuh. Berkebalikan dengan hidrasi, dehidrasi berarti kurangnya cairan di dalam tubuh karena jumlah cairan yang keluar lebih besar daripada jumlah yang masuk.

Bagi cabang-cabang olahraga outdoor seperti atletik, triathlon, dll dimana tubuh 
menerima panas dari luar akan banyak mengeluarkan cairan melalui keringat. Meskipun tidak menutup kemungkinan olahraga didalam gedung (indoor) juga akan mengalami hal yang sama. Sehingga sangat penting untuk memperhatikan keseimbangan cairan dalam tubuh bagi atlet saat latihan maupun bertanding.

Keseimbangan cairan diperlukan untuk mempertahankan volume darah, mengatur suhu tubuh dan terlibat dalam kontraksi otot. Pengeluaran keringat akan diatur oleh sistem saraf otonom dan dikendalikan secara tidak sadar oleh hipotalamus; struktur di otak yang mengatur status quo tubuh. Berkeringat adalah cara utama tubuh mempertahankan suhu tubuh yang optimal. Mengkonsumsi cairan mengisi kembali cairan (rehidrasi) yang hilang saat berolahraga akan mengembalikan cairan dan mempertahankan fungsi otot normal, membantu mencegah penurunan kinerja fisik dan mengurangi risiko tekanan panas pada tubuh. Gejala tekanan panas saat berolahraga dapat menimbulkan takikardia, hipotensi, hiperventilasi, muntah, diare, kejang, dan bahkan koma.

Inilah 4 alasan utama mengapa dehidrasi berdampak buruk pada performa latihan pada remaja antara lain:

Pengurangan volume darah - Dehidrasi dapat menyebabkan peningkatan tekanan darah. Ini terjadi karena dehidrasi mengurangi volume darah, maka tubuh Anda harus menggantinya dengan mempertahankan lebih banyak natrium dalam darah. Ketika darah menjadi lebih terkonsentrasi dan lebih tebal, lebih sulit untuk bersirkulasi menyebabkan jantung Anda bekerja lebih keras.

Berkurangnya keringat - Keringat adalah salah satu cara tubuh kita mengatur suhu dan terdiri dari sekitar 95 persen air. Jika Anda tidak minum cukup air, Anda tidak bisa berkeringat. Ketika tubuh tidak dapat secara efektif mengatur suhu Anda menempatkan diri Anda pada peningkatan risiko stroke panas dan kelelahan panas.

Distribusi panas menurun - Batas dehidrasi respons kardiovaskular dan termoregulasi. Ini menyebabkan peningkatan suhu inti. Untuk setiap $1 \%$ penurunan berat badan karena air ada peningkatan suhu inti dari 0,10 hingga 0,40 derajat Celcius.

Peningkatan tingkat penggunaan glikogen otot Konsentrasi glikogen otot menurun selama latihan yang lama atau aktivitas atletik. Glikogen berfungsi sebagai bentuk penyimpanan energi. Glikogen yang menipis berkontribusi pada kelelahan otot.

Remaja dengan tingkat aktifitas berat dan berkaitan dengan panas suhu tubuh memiliki tingkat dehidrasi yang tinggi. Para peneliti menemukan atlet remaja cenderung mengalami dehidrasi sebanyak $2,5 \%$ dari berat badan melalui keringat dan mengalami penurunan hingga $45 \%$ kapasitas saat melakukan latihan dengan intensitas tinggi. Beberapa gejala yang muncul terjadinya dehidrasi antara lain Bibir dan lidah kering, mata cekung, urin berwarna cerah atau gelap, atau urin dengan bau yang kuat, sering buang air kecil, volume urin kecil, kekurangan Energi, dan penurunan kinerja secara tiba-tiba

Secara konservatif sebagai asupan cairan per jam yang dibutuhkan sebesar $13 \mathrm{~mL} / \mathrm{kg}$ (6 $\mathrm{mL} / \mathrm{lb})$ berat badan $4 \mathrm{~mL} / \mathrm{kg}(2 \mathrm{~mL} / \mathrm{lb}$ ] untuk setiap jam latihan) untuk menghindari dehidrasi. Atau paling tidak Minumlah sekitar 2 gelas atau 480 mililiter air 2 jam sebelum latihan. Pada saat berolahraga, minumlah sekitar $1 / 2$ hingga 1 gelas (120 hingga 240 mililiter) cairan setiap 15 hingga 20 menit. Hidrasipada atlet yang tepat membutuhkan asupan cairan sebelum, selama dan setelah latihan atau aktivitas. Jumlah cairan yang dibutuhkan tergantung pada banyak faktor, termasuk usia dan ukuran tubuh.

Tabel. Kebutuhan Asupan cairan minimal pada atlet remaja

\begin{tabular}{|c|c|c|}
\hline $\begin{array}{c}\text { Berat } \\
\text { Badan } \\
(\mathrm{kg})\end{array}$ & $\begin{array}{c}\text { Cairan selama } \\
\text { latihan (ml/jam) }\end{array}$ & $\begin{array}{c}\text { Penggantian cairan } \\
\text { setelah latihan } \\
(\mathrm{ml} / \text { jam })\end{array}$ \\
\hline 25 & 325 & 100 \\
\hline 30 & 390 & 120 \\
\hline 35 & 455 & 140 \\
\hline 40 & 520 & 160 \\
\hline 45 & 585 & 180 \\
\hline
\end{tabular}




\begin{tabular}{|l|l|l|}
50 & 650 & 200 \\
\hline 55 & 715 & 220 \\
\hline 60 & 780 & 240 \\
\hline
\end{tabular}

Rowland $\mathrm{T}$ merekomendasikan asupan cairan minimal yang disarankan selama dan setelah berolahraga pada atlet remaja, berdasarkan pada perhitungan $13 \mathrm{~mL} \mathrm{/} \mathrm{kg}$ selama latihan dan $4 \mathrm{~mL} / \mathrm{kg}$ setelah latihan.

Untuk memenuhi kebutuhan cairan dapat menggunakan minuman maupun minuman berenergi, air vitamin dan minuman berkafein tinggi. Minuman olahraga dan energi saat ini banyak tersedia dan banyak yang mengandung elektrolit. Minuman untuk menghasilkan energi biasanya mengandung gula (karbohidrat) maupun kandungan elektrolit seperti natrium dan kalium. meskipun begitu pada dasarnya atlet hanya membutuhkan air putih agar tetap terhidrasi.

Bagi kebanyakan remaja, minum air sebelum, selama, dan setelah berolahraga akan membuat mereka tetap terhidrasi. Sebenarnya yang terbaik adalah lebih baik menghindarkan atlet untuk mengkonsumsi minuman berenergi karena masih banyak bahan-bahan yang kandungannyua belum diteliti efek sampingnya dan cenderung berbahaya.

\section{Waktu (timing)}

Pemenuhan nutrisi yang seimbang adalah prioritas bagi atlet remaja, namun menentukan waktu makan sama pentingnya untuk mengoptimalkan kinerja dan pemulihan olahraga. Untuk memenuhi kebutuhan nutrisi, para ahli menyarankan untuk sering mengonsumsi makanan di luar sarapan, makan siang dan makan malam. Terlebih dengan aktifitas yang dilakukan diluar jadwal latihan disarankan atlet mengkonsumsi makanan kirakira setiap tiga jam sekali untuk meminimalkan defisit energi tiap harinya. Secara umum, dinamika asupan energi harus sesuai dengan dinamika pengeluaran energi saat beraktifitas. Paling tidak atlet pelatih atau ahli gizi perlu memahami dan bisa mengatur waktu makan sebelum, pada saat dan sesudah latihan atau bertanding.

Tujuan dari pemberian makanan atau cemilan sebelum berolahraga adalah untuk meningkatkan atau menyimpan energi (glikogen hati dan otot) dan untuk memastikan bahwa atlet merasa nyaman dan tidak merasa lapar atau terlalu kenyang.

Sebelum latihan/bertanding, biasanya karbohidrat tinggi dan makanan rendah lemak atau cemilan perlu dikonsumsi, sedangkan makanan dengan lemak tinggi dan serat tinggi perlu dihindari untuk mencegah keterlambatan pengosongan perut guna menghindari kram. Makan sebelum berolahraga paling tidak mengandung sekitar 10-25\% kalori dari protein, dengan upaya untuk menghilangkan rasa lapar.

Secara umum, atlet remaja harus mengonsumsi makanan normal (400 kkal) sekitar 3-4 jam sebelum berolahraga atau makanan ringan (200 kkal) sekitar 1-2 jam sebelum berolahraga. Semakin dekat waktu makan dengan latihan, semakin sedikit kalori yang mereka konsumsi untuk menghindari sakit perut. Dianjurkan untuk tidak makan dalam waktu 30 menit sebelum olahraga.

Selama latihan/bertanding. konsumsi bahan bakar selama berolahraga adalah untuk mempertahankan energi dan memaksimalkan kinerja. Untuk latihan atau pertandingan yang berlangsung kurang dari 60 menit, bahan bakar selama latihan seringkali tidak diperlukan.

Saat latihan atau pertandingan yang berlangsung lebih lama dari 60 menit konsumsi asupan sebaiknya berasal dari minuman olahraga, yang mengandung karbohidrat dan elektrolit dengan kadar 6-8\% gula, sehingga cepat diserap dan digunakan untuk energi. Soda dan jus buah $100 \%$ harus dihindari selama berolahraga, karena kadar gula dan kafein yang tinggi dapat menyebabkan sakit perut. Atlet remaja juga dapat mengambil manfaat dari konsumsi camilan buah hidrasi, seperti jeruk, melon, dan blewah selama pertandingan atau kompetisi yang panjang.

Setelah latihan/bertanding. Tujuan konsumsi bahan bakar setelah mengikuti latihan adalah untuk mendukung pemulihan dan 
perbaikan jaringan atlet remaja yang sedang tumbuh serta menggantikan simpanan glikogen dalam hati dan otot. Konsumsi makanan setelah latihan atau bertanding harus mengandung karbohidrat dan protein. Konsumsi makanan tinggi karbohidrat dengan protein tinggi setelah berolahraga membantu memulihkan glikogen otot. Makanan yang dikonsumsi 3 jam setelah latihan perlu mengandung karbohidrat tinggi, tetapi rendah lemak dan serat, sehingga gula di dalamnya akan dengan remajah dengan cepat mengalir dalam darah dan menggantikan simpanan glikogen. Sebaiknya mengurangi makanan cepat saji, gorengan dan makanan olahan setelah latihan.

\section{Suplemen (Supplementation)}

Pada atlet remaja kebutuhan energi menjadi kebutuhan dasar yang penting selama melakukan latihan atau pertandingan. Sehingga tidak jarang mereka akan menggunakan cara pintas seperti penggunaan zat atau suplemen yang terkadang cenderung berbahaya bagi tubuhnya. Orang tua, pelatih maupun atlet setidaknya perlu memahami jenis suplemen yang sesuai dan baik digunakan sebagai pengganti asupan energi secara cepat. Terlebih pelatih harus memahami jenis suplemen agar terhindar dari doping dalam kompetisi/ pertandingan.

Atlet remaja sering menggunakan suplemen protein atau suplemen asam nukleat (creatine) untuk membantu kinerja olahraga mereka. Penelitian menunjukkan suplemen ini belum membantu meningkatkan kinerja olahraga pada atlet remaja. Selama masa pubertas atlet tumbuh dan menjadi lebih kuat dan kinerjanya sering meningkat dengan sangat cepat. Creatine tampaknya tidak memberikan manfaat tambahan apa pun pada kelompok usia ini. Kebanyakan atlet remaja yang makan makanan sehat dan seimbang tidak perlu dan tidak akan mendapat manfaat dari suplemen protein.

Suplemen selanjutnya adalah minuman berenergi maupun kafein. Mengkonsumsi terlalu banyak kafein, seperti yang ditemukan dalam bubuk, pil, dan banyak minuman berenergi, bisa berbahaya. Meskipun kafein tampaknya meningkatkan kinerja olahraga pada beberapa orang dewasa, efeknya sangat bervariasi. Efek kafein belum dipelajari dengan baik pada anakanak dan remaja. Atlet remaja yang minum obat untuk gangguan/hiperaktif harus sangat berhatihati ketika menggunakan minuman berenergi yang mengandung stimulan.

Efek penggunaan suplemen pada pertumbuhan dan perkembangan anak-anak dan remaja tetap tidak jelas dan dengan demikian penggunaan suplemen oleh remaja khususnya atlet ini perlu dihindari.

\section{PEMBAHASAN}

Berdasarkan tujuan dari penulisan bahwa artikel ini lebih menjelaskan pada aspek yang harus diperhatikan dalam pemenuhan nutrisi pada atlet remaja. Berikut ini penjelasan aspek dan apa yang harus diperhatikan dalam memenuhi kebutuhan nutrisi bagi atlet remaja.

\section{Kebutuhan Nutrisi pada atlet Remaja}

Atlet merupakan seseorang yang memiliki aktifitas fisik dan kebutuhan energi yang berbeda dengan orang pada umumnya. Aktifitas fisik pada atlet membutuhkan asupan energi melalui nutrisi yang tepat. Nutrisi dapat membuat perbedaan antara atlet yang baik dan hebat. Pemberian nutrisi yang tepat membantu mempertahankan energi selama berolahraga, memastikan konsentrasi glukosa darah normal, mencegah rasa lapar, menjaga massa otot, dan mempercepat pemulihan. Meskipun kebutuhan energi lebih tinggi, sumber makanan yang direkomendasikan untuk atlet remaja tidak menyimpang jauh dari rekomendasi umum untuk kesehatan yang optimal.

Pemberian nutrisi yang tepat pada atlet remaja akan berdampak pada penampilan atlet saat latihan maupun bertanding. Nutrisi akan sangat membantu atlet meningkatkan performa melalui Energi yang dihasilkan, menunda kelelahan (fatique), meningkatkan kekuatan dan fokus serta mempercepat proses pemulihan (Recovery). Pada dasarnya atlet untuk dapat mencapai performa terbaiknya sangat perlu untuk memperhatikan asupan nutrisinya. 
Nutrisi yang tepat untuk atlet remaja tidak hanya penting untuk menjaga kesehatan dan mengoptimalkan kinerja olahraga, tetapi juga sangat penting untuk memenuhi persyaratan pertumbuhan dan perkembangan. Selain konsumsi kalori yang memadai dan nutrisi seimbang untuk pertumbuhan dan kinerja, pemilihan waktu harus menjadi pertimbangan utama bagi atlet remaja. Beberapa hal yang harus diperhatikan dalam menentukan nutrisi yang tepat antara lain:

1. Kebutuhan kalori (Calorie Needs)

2. Makronutrient (Macronutrient)

3. Hidrasi (Hydration)

4. Waktu (timing)

5. Suplemen (Supplementation)

Dari beberapa hal tersebut diatas, perlu dipahami faktor -faktor yang mempengaruhi pemberian nutrisi yang tepat seperti jenis olahraga, gen, jenis kelamin, maupun usia.

\section{KESIMPULAN}

Disimpulkan bahwa dalam memenuhi kebutuhan nutrisi atlet kita harus memperhatikan beberapa aspek. Aspek kebutuhan nutrisi yang harus diperhatikan antara lain kebutuhan kalori (calorie needs), makro nutrient (macro nutrient), hidrasi (hydration), waktu (timing), suplemen (supplementation).

\section{UCAPAN TERIMAKASIH}

Ucapan terima kasih disampaikan kepada program studi Pendidikan Jasmani Kesehatan dan Rekreasi, Fakultas Keguruan dan Ilmu Pendidikan Universitas Wahid Hasyim Semarang.

\section{REFERENSI}

\section{Journal}

Ami W. Anzilotti, MD. (2019). Sport Drink and Energi Drinks. https://kidshealth.org /en/teens/sports-Energi-drinks.html? WT.ac $=$ ctg \#catnutrition (diakses pada 18 Oktober 2019)

Ben Desbrow, Nicholas A Burd, etc. (2019). Nutrition for Special Populations: Young, Female, and Masters Athletes (Journal) International Journal Of
Sport Nutrition, Exercise and metabolism

Ilaria St. Florian, MS, RD. (2018). The 101 on Nutrition in Young Athletes. https://www.stamfordhealth.org/healt hflash-blog/fitness-wellness/nutrition-

J. Clifford and K. Maloney. Nutrition for Athletes. Journal of Colorado State University, 9362 Fact. Sheet No. 7/15.

Jennifer Sacheck, Ph.D. and Nicole Schultz, M.S., MPH. Optimal Nutrition for Youth Athletes: Food Sources and Fuel Timing. National Youth Sports Health \& Safety Institute.

Jovanov Pavle , Đorđić Višnja , etc (2019) Prevalence, Knowledge and Attitudes Towards Using Sports Supplements Among Young Athletes. Journal Of International Society of Sport Nutrition

LutheranHospital. Hydration Tips for Young Athletes. Lutheran Weight Management Center and Lutheran Nutritional Services. www.lutheranhospital.com (diakses pada 16 Oktober 2019)

Mary L. Gavin, MD. (2015). Feeding Your Child Athlete. https://kidshealth.org/en/ parents/feed-child-athlete.html (diunduh pada 15 Oktober 2019)

Meyer F, O'Connor H, Shirreffs SM. (2009). Nutrition for the young athlete. https://www.ncbi.nlm.nih.gov/pubme d/18049985/. (diakses pada 10 Oktober 2019)

PR Cole, MS and Timothy Trainor, MD (2009). Nutrition for Athletes. (International Journal) Nutrition and Athletic Performance position paper of the American College of Sports Medicine

Ronald J. Maughan. (2000). Nutrition in Sport (International Journal Volume VII of the Encyclopaedia of Sports Medicine an Ioc Medical Commission Publication). Blackwell Science Ltd

Rowland T. (2011). Fluid replacement requirements for child athletes. https://www.ncbi.nlm.nih.gov/pubme $\mathrm{d} / 21425887 /$. (diakses pada 10 Oktober 2019) 
Smith JEW, Holmes ME, McAllister MJ (2015).

Nutritional Considerations for Performance in Young Athletes (International journal Of Sport Medicine) 